\title{
WEBER, NIETZSCHE E AS RESPOSTAS ÉTICAS À CRÍTICA DA MODERNIDADE ${ }^{1}$
}

\author{
Renarde Freire NOBRE ${ }^{2}$
}

- RESUMO: O artigo consiste num estudo comparativo entre as concepções de cultura de Friedrich Nietzsche e Max Weber, suas análises críticas da modernidade e as respostas éticas que as acompanham. Apesar das importantes afinidades encontradas entre os autores, o artigo procura mostrar que o caráter principal da comparação entre os seus pensamentos é o do desencontro e da incompatibilidade.

- PALAVRAS-CHAVE: Cultura; modernidade; ética; racionalidade.

Todos os julgamentos instintivos são míopes em relação à cadeia das conseqüências: aconselham o que convém ser feito em primeiro lugar.

Nietzsche, VP, §356, p.272

Procuraremos trabalhar e atender às 'exigências do momento' nas relações humanas e em nossa vocação. Isto, porém, é claro e simples, se cada um de nós encontrar e obedecer ao demônio que controla os cordões de nossa própria vida.

Weber, WB, p. $273^{3}$

\footnotetext{
$1 \mathrm{O}$ presente texto retoma e amplia idéias apresentadas na XXVI Jornada de Filosofia e Teoria da Ciências Humanas - a filosofia da existência e a tragédia moderna, na UNESP/Marília, em $6 / 11 / 02$.

2 Departamento de Sociologia e Antropologia - UFMG

3 As siglas adotadas se referem às obras consultadas de Nietzsche e de Weber, cuja relação consta da bibliografia. Nas referências, sempre que a fonte foi o alemão, esta foi cotejada com as traduções disponíveis, cuja congênere, em português, é, por vezes, distinguida pelo sinal gráfico "[ ]".
} 
Este texto visa estabelecer paralelos entre as respostas éticas fornecidas por Friedrich Nietzsche (1844-1900) e Max Weber (1864-1921) face às suas análises críticas da cultura moderna. ${ }^{4}$ Fundamentalmente trata-se de investigar os pontos de encontro e de desencontro entre os dois autores sobre o tema conforme três níveis de reflexão: a imagem geral da cultura, a interpretação crítica da cultura moderna e a resposta ética decorrente dessa crítica, tema este que receberá uma reflexão mais detalhada. Na estruturação do texto, cada nível será abordado primeiro conforme o que apresenta de afinidades e, depois, de diferenças entre os autores, de modo que os encontros e os desencontros serão tratados a partir de planos comuns.

\section{Parte I:}

\section{Dos encontros}

\section{A imagem geral da cultura}

Weber compartilha com Nietzsche um pressuposto fundamental a respeito da cultura (e da vida como um todo): o seu caráter perspectivista e agonístico. Examinemos a primeira qualificação. Ela consiste na idéia de que as ações e vivências humanas possuem sentidos múltiplos em cuja singularidade são irredutíveis umas às outras, expressando finalidades últimas incondicionadas ou irracionais. As metas e as justificações maiores dos homens não são objetos de uma lei objetiva nem tampouco produtos de um entendimento consciente e autônomo, mas sim modos de valoração subjetivamente fundamentados. O perspectivismo supõe, pois, a combinação dos princípios da subjetividade e da singularidade das ações ou das interpretações.

\footnotetext{
4 Ao referir-me à "cultura moderna" devo pontuar que o adjetivo que acompanha a expressão não foi igualmente "historicizado" pelos autores. Weber associou sua idéia de "moderno" aos processos históricos mais contemporâneos, posteriores à Idade Média, os quais, por mais que guardassem resquícios de um passado mais distante - como o legado grego do "conceito" para a ciência moderna ou os antigos traços religiosos - foram realçados conforme as singularidades que adquiriram no decorrer dos últimos três ou quatro séculos no Ocidente. Nietzsche, por sua vez, tem uma visão, digamos assim, mais ampla da modernidade cultural, sustentando-a nas condições milenares do cristianismo e do racionalismo intelectual, embora não despreze os "recortes históricos" e dê destaque às manifestações mais atuais da tradição moderna do Ocidente. Há a preocupação comum com a atualização das análises, mas distintas são as formas de conectar o passado e distintas as ênfases quanto às bases históricas decisivas do presente.
} 
Nietzsche foi, sem dúvida, o pensador moderno que primeiramente radicalizou estes dois princípios dentro do seu perspectivismo, operando a subjetivação plena do conhecimento como estudo do aparente e do arbitrário. A seu juízo, todo modo de vida - incluindo as formas não humanas - é a expressão de uma subjetividade em ação, cuja manifestação é arbitrária por não remeter a um outro modo de vida, pois não se trata da mecânica "causa e efeito", e é aparente porque um modo de aparecer (e perecer) e, não, um modo de "ser". Nietzsche vangloriou-se exatamente de combater as doutrinas "mecanicistas" e "essencialistas" contidas nas ciências modernas e em toda a metafísica.

Weber, por seu turno, explicitou-nos o seu perspectivismo quando postulou para as ciências da cultura uma concepção das ações humanas como condutas subjetivamente orientadas. $\mathrm{O}$ fato de serem orientações implica que as ações não possuem um sentido dado; o fato de serem subjetivas revela o caráter eminentemente singular e representativo dos sentidos (Cohn, in ES, p.XIV). Assim, por mais racionalizadas que se mostrem as condições da ação, ou seja, por mais conscientes e evidentes os elementos que compõem a representação que guia a ação (em especial, se pensados como meios e fins), esta nunca deixa de ser um ato essencialmente subjetivo (não se torna mera efetivação de fatos objetivos, como em Durkheim) e parcial, pois o sentido visado é sempre relativo ao agente interessado e ao contexto societário em que este age (não é uma objetividade externa ou um a priori qualquer).

A aceitação do subjetivismo e da singularidade como princípios inerentes às ações humanas corresponde ao postulado weberiano de uma ciência da cultura que lide com "tipos ideais", pois é a "tipificação" uma confirmação de que todo conhecimento parte de um ponto de vista particular e "a idealização", uma confirmação de que a objetividade (ou a pureza lógica) não é uma propriedade da realidade mas, sim, da representação teórica. E, como Nietzsche - embora de forma não tão radical e sem abrir mão da "adequação causal" -, Weber também recusará o mecanicismo clássico, ao pensar em termos de multiplicidade causal (e não de causa "eficiente") e de reciprocidade causal (princípio das "afinidades eletivas", válido de modo geral para as importantes relações entre interesses ideais e interesses materiais).

Um ponto forte de convergência dos dois pensadores é, sem dúvida, a recusa de uma concepção "substancialista" do conhecimento, quando os conceitos são tomados como representação fidedigna de fatos. Há um traço de kantismo na postura que visa afirmar o grau de artificialidade na fabricação do conceito face à experimentação. Porém, para Weber - bem 
mais à vontade com Kant do que Nietzsche - de nada valem as formações conceituais se elas não procuram aproximar-se da realidade e confirmar-se em evidências empíricas. Já para Nietzsche - muito mais radical no seu anti-substancialismo - os conceitos devem afirmar a sua condição metafórica e visar sua auto-afirmação e, não, sua confirmação em fontes externas, porque, para ele, estas definitivamente não existem; as ciências não são "explicativas", mas "descritivas". Todavia, a despeito da diferença na intensidade da crítica ao substancialismo, Weber e Nietzsche tratavam igualmente os conceitos como tipificações baseadas em pontos de vista, ou perspectivas forjadas num nível pré-investigativo. Mesmo apostando na validação empírica do conceito, Weber asseverava que ele não é um "juízo", não tem valor absoluto, nem é uma "coisa"; aliás, um equívoco tende a implicar no outro, como aconteceu com o marxismo. Assim pensando, ele rejeita o conceito tanto como apologia de um dado sentido - idéia de valor tomada como "dever ser" - quanto como empobrecimento do real - em desrespeito ao seu caráter múltiplo e fluido. ${ }^{5}$ De todo modo, Weber foi bem menos severo que Nietzsche ao separar a lógica e o real, concebendo e procurando fortes confirmações empíricas das abstrações causais; na verdade, para ele, a lógica não era tão artificial quanto parecia a Nietzsche.

Ambos consideravam a realidade um decurso contínuo de ações ou forças e que somente a título de apreensão inteligível é que os fatos podem ser isolados numa abstração bem definida de "causas e efeitos". Nietzsche foi ainda mais severo neste ponto: "causa e efeito: trata-se de uma dualidade que decerto nunca existirá; assistimos na verdade a uma continuidade de que isolamos algumas partes" (FW, §112). O ponto comum está na visão da descontinuidade como um recurso da lógica e, não, como realidade. Weber adotou o princípio da descontinuidade como base da racionalidade lógica e técnica, tanto que a ação mais lógica e evidente que existe - a "ação racional referente a fins" -, base da sua metodologia e presente também na ética, prescreve a separação entre sujeito e objeto e entre agente e ação.

Aceitando-se que o império de uma consciência racional seria o governo do "técnico", o império do Deus ex-machina, Weber e Nietzsche o consideravam uma impossibilidade, dado o fato de que toda racionalidade é cultural e, portanto, remete a uma raiz valorativa. Os valores

5 Os diferentes modos de resgatar a singularidade: a interpretação racionalista de Weber que trata de singularidades racionalizadas e a interpretação psicológica de Nietzsche, que trata das singularidades como transfigurações de afetos. 
ou motivos últimos estão isentos de uma significação racional stritu senso; assim, não se elevam plenamente à consciência, associados que estão a um registro incomunicável, como uma intenção que se sublima para ganhar força significativa. Vimos que essa é a essência do perspectivismo. Não há razão desinteressada. E, se a razão não pode justificar-se a si mesma, a justificação só pode vir "de fora"? Mas onde é o "de fora" da razão? De onde vêm os "motivos" que perpassam a consciência e seus efeitos racionais? Onde encontrar os "fins últimos" subjacentes a todo procedimento racional? Só podem referir-se à não-razão, ao irracional; numa sentença: só podem "estar" naquela "dimensão" em que as vivências racionais ou conscientes se sustêm como "disposição", independentemente das considerações sobre a sua factualidade. Assim, as racionalizações, não podendo se autojustificar, ficam condenadas à condição perspectivista. A própria ciência, por mais operante e hegemônica que se demonstre, participa da dimensão perspectivista da vida.

O segundo pressuposto a respeito da cultura (e da vida) é o seu caráter agonístico. O que denominamos "realidade" é apenas um amálgama amorfo de sentidos diferenciados mas interrelacionados, cuja impossibilidade de constituírem um equilíbrio sistêmico está no fato de se negarem mutuamente quanto às suas condições últimas, ou seja, no fato de visarem, por princípio, a afirmação de uma singularidade, não importando, neste momento, como esta é caracterizada em cada autor. Para ambos, o curso de uma ação ou o fluxo de uma força só se efetiva sob tensão com outros cursos possíveis, o que, no limite, é algo insuperável, pois as singularidades se chocam ao ocuparem os seus "espaços" em configurações de ações ou de forças. Do caráter agonístico da existência decorre a relevância de noções como as de "luta", "seleção", "poder" e "dominação", todas elas centrais nas análises culturais de Nietzsche e Weber. Os dois viam as configurações de relações de sentidos efetivos como demarcadas por hierarquias (princípio da dominação) e tensões (princípio da incompatibilidade última). É preciso ponderar que as oposições não se processam de modo absoluto - mesmo porque ações e forças não designam "substâncias", apenas processos - mas só se manifestam através de conflitos circunstanciais, havendo sempre fluidez e continuidade real entre as "fronteiras" dos sentidos que compõem uma dada configuração. As singularidades - e consequentemente as oposições entre elas - só se impõem por "efetivação", quando os procedimentos se fazem reconhecidos nos seus decursos e manifestações (históricas). A vida é sinônimo de efetivação, e tudo que se efetiva indispõe-se e luta. Mas, como não há 
efetivação pura - Weber a aceita apenas como raridade -, a singularidade só pode ser experienciada de modo tipificado.

Perspectivismo e luta são, pois, propriedades do mundo cultural que remetem a um fato decisivo: na sua fundamentação mais íntima, anteriormente ao plano das "efetivações culturais" - entendimentos, socializações, legitimações, imposições, hábitos, convenções, crenças, etc. -, o fluxo dos sentidos é absolutamente arbitrário, sendo imprecisos o começo e o término de um devir. A arbitrariedade ou irracionalidade inscreve-se pois no núcleo da cultura. $\mathrm{O}$ fundo inefável atrás das intencionalidades conscientes e das certezas racionais, a presença do acaso na existência, o caráter abstrato ou probabilístico de toda unidade, o drama da imprevisibilidade última de todo "vir-a-ser", o "sem sentido" decisivo da vida humana: são todos princípios básicos com os quais Nietzsche e Weber fizeram coro.

Em síntese, as idéias expostas neste item indicam uma concepção comum da cultura como um complexo de procedimentos significativos ou valorações subjetivas, através das quais os homens, como portadores, conferem sentido à sua existência. Ações e forças são as unidades de processamento dos sentidos para Weber e Nietzsche, respectivamente. Tais procedimentos, por mais que possam ser objeto de uma elaboração consciente, remontam a motivos que repousam num fundo irracional e contínuo, por isso não podem ser diretamente apreendidos enquanto leis empíricas nem enquanto totalidade, mas tão somente como valorações, interesses, perspectivas. Ao mesmo tempo, enquanto subjetivações, só podem ser pensados como singularidades auto-referidas, em contraposição a quaisquer posturas "transcendentalistas" ou "deterministas". Mas também não se trata de uma autonomia, porque não há essências nem império absoluto da consciência; Weber e Nietzsche conferiram às ações e às forças o atributo da singularidade (e não da autonomia plena), pressupondo-se que cada uma segue sua dinâmica própria e, no íntimo, inconciliável com as demais.

\section{A interpretação crítica da cultura moderna}

Se Nietzsche e Weber conceberam a cultura como um complexo de forças e ações significativas, também convergem quanto à visão da contemporaneidade cultural como o movimento mais profundo de desvaloração das significações superiores. Nietzsche sintetizou a crise moderna 
dos grandes valores, quer de extração religiosa ou filosófica, pela expressão "morte de Deus", cuja principal sintomatologia está na intensificação do niilismo nas almas modernas (VP, §2, p.86). Instaura-se um "niilismo passivo" no apogeu da perda dos sentidos tradicionais, como acentua Machado (1997), em que as almas mais conscienciosas são tomadas por um inevitável sentimento de inutilidade de todas as crenças metafísicas, quando toda a história da humanidade pode parecer "em vão" e o homem sofre da própria "doença" das falsidades e ingenuidades que ele criou. Sofre-se pela constatação da inexistência de todo "em si", de toda "unidade" e de todo "além" na existência. Disse Nietzsche: "A mais geral característica dos tempos modernos: o homem desmereceu, ante seus próprios olhos, infinitamente em dignidade" (VP, §4, p.88).

Como sintomatologia de um instinto de decadência, o "niilismo passivo" representa uma disposição fisiológica e psicológica negativa: a "vontade do nada" (GM, III, §28). O "nada" é a natureza de todas as "tábuas de valores" com as quais os homens conferem um sentido absoluto (moral) aos acontecimentos, afrontando o caráter aparente, múltiplo e imanente da existência efetiva. O "nada" está no "além", na "unidade", no "em si". E, para Nietzsche, "enquanto cremos na moral, condenamos a existência". É por força mesmo dessa vontade decadente, a "vontade do nada", que os espíritos modernos mais criativos, angustiados pela percepção íntima do "deus morto" e incapazes de afirmarem o mundo tal como ele se descortinou, transferem suas últimas esperanças para os valores seculares, em especial a razão esclarecida e a igualdade legal, e para as forças do progresso material. Com Zaratustra, temos a metaforização dessa busca nos "homens superiores" que "gritam" por socorro ou reverenciam o "asno" (ZA, IV Parte). Para Nietzsche, tratava-se de um modo de intensificação da doença da qual o niilismo passivo é a grande sintomatologia, porque o que opera por detrás das crenças na ciência, na democracia ou no progresso é a velha "vontade do nada". O problema estava em que "o maior acontecimento - 'Deus morreu' - [era apenas] surdamente pressentido" (VP, §1, p.85).

Weber seguiu o diagnóstico nietzscheano num aspecto essencial: era preciso encarar de frente a depreciação histórica dos valores superiores. Embora a interpretação dos motivos de tal acontecimento bem como o projeto ético de enfrentamento destoe bastante entre os dois pensadores, o que nos importa agora é a convergência com a idéia de que a vida não guarda sentidos absolutos ou universais, uma idéia que demarcava os espíritos mais modernos. A falta de sentido da existência não é um dado, mas refere-se a uma "perda", embora não deixe de ser a perda de uma ilu- 
são; porque, de fato, não há sentido absoluto. Nietzsche não disse "deus não existiu" mas, sim, "deus morreu"; e, em Weber, a perda era decorrência da afirmação de processos racionalizadores que pulverizavam os sentidos e subtraíam das ações a pretensão de corresponderem, como antes, a uma totalidade significativa. A "perda de sentido", como é mais apropriado dizer, não era tanto uma questão de princípio (a falta de), mas uma experiência histórica dos homens, quer esta receba uma ênfase psicológica (Nietzsche) ou sociológica (Weber).

Por fim, a crise dos valores indicava também uma perda de sublimidade. O mal tinha que ser reconhecido porque não havia mais como negá-lo através de uma valoração metafísica da bondade. Bem e mal são definitivamente referidos às interpretações; e, por vezes, o mal mostrava-se o melhor caminho para o bem, seja esta relação pensada mais no âmbito da política (Weber) ou estendida para o conjunto da existência (Nietzsche). E a crise também configurava uma perda no potencial de criação. Weber e Nietzsche concebiam os tempos áureos como períodos de criação, e os criadores como grandes homens. As condições modernas de vida mostravam-se inóspitas ao aparecimento desses tipos extraordinários, quer porque impunham a especialização, quer porque enalteciam a opinião da maioria.

Weber recolocou o problema da "perda de sentido" e da "morte de Deus" fundamentalmente pela idéia de desencantamento do mundo. Por um lado, ela designava a fragmentação das "esferas culturais" devido aos processos históricos de racionalização; por outro, designava a expulsão dos valores superiores para o âmbito do misticismo ou das vivências mais íntimas devido à disseminação de procedimentos formais nas esferas mais cotidianas. Ou seja, uma faceta cultural (politeísmo de valores) e uma faceta societária (formalismo ou racionalismo de domínio do mundo), fenômenos que profanavam definitivamente a ingenuidade do homem quanto à unidade e à essencialidade dos valores. Weber tomou emprestada de Goethe a idéia de que o homem não podia mais experienciar a "universalidade faustiana" e "saciar-se" da vida, uma vez que era herdeiro dos processos de cultivação racional dos valores, que o condenavam a experimentar a existência de modo parcelado.

Embora todo o processo seja de cunho secular, sabemos o quanto Weber apontou para as influências religiosas do desencantamento do mundo. Se é certo que a última e mais decisiva dessas influências remete ao caráter radicalmente ativo da ética ascética puritana, houve, muito antes, toda a tradição judaica e cristã portadora de um ascetismo associado ao perfil de camadas urbanas com fortes interesses práticos; mais 
especificamente, o judaísmo antigo foi a primeira grande religião a racionalizar a magia de modo coerente. Quanto ao puritanismo, a sua conformação ética de um desencantamento secular consistia, para Weber, na radicalização do princípio da conduta "consciente", "desperta" e "conseqüente" como "prova" para a "certeza da graça" (WG, p.311, [ES, 366]); uma entrega vocacionada às tarefas mundanas que dispensava a compreensão do sentido do mundo. O puritano oferece sua alma ao parcelamento nas ordens do mundo como um desígnio do Senhor, confiando a um Deus absconditus o problema do sentido da existência, suas graças e seus infortúnios - tarefa levada a termo pela teodicéia calvinista da predestinação, com todas as suas conseqüências não-previsíveis. Outra singularidade é que a ética profissional mundana promove a particularização da graça e a ruptura com as grandes éticas religiosas fundadas na fraternidade do "amor acósmico" (EX, p. 536). Se acrescentarmos a forte inclinação para o ethos burguês, temos as razões por que o puritanismo foi por Weber apresentado como uma motivação ética decisiva para a estruturação de um desencantamento de faceta pós-religiosa.

A ética puritana, contudo, levou uma rasteira e viu-se secundarizada. O sentido "vocacional" da ética puritana - a atividade ascética no mundo entendida como um chamado divino - dessubstancializa-se para indicar um sentido profissional - a atividade mundana como obrigação decorrente da submissão do indivíduo às leis societárias -, portanto, sem o sentido de um "chamado". 6 A análise weberiana do racionalismo secular que hegemoniza as relações sociais modernas aponta para a compressão dos espaços societários de regulação ética (racionalidade material) por força da emergência e consolidação de condições impessoais que exigiam um outro tipo de garantia: a regulação formal. No confronto entre a universalidade ética e a impessoalidade formal, a ética tenderá, como veremos, a se confinar nas barreiras da subjetividade e da intimidade, mesmo enquanto fenômeno religioso. E é interessante observarmos como por um mecanismo de compulsão racionalizadora dinamizado em várias áreas da vida processava-se uma dupla configuração, apenas aparentemente contraditória: por um lado, a presença de um sentido societário hegemônico de caráter "adaptativo", expresso pela noção de "racionalismo de domínio do mundo"; por outro lado, uma efetiva perda de sentido em vista da autonomização de cursos de ação que, assim, estão em tensão uns contra os outros. Neste sentido, os processos de racionali-

6 O substantivo alemão Beruf (Ruf=chamado), que originalmente designava a idéia de "vocação", passa a designar "profissão". 
zação cultural sedimentavam o caráter trágico e não "adaptativo" da cultura - embora não o inaugurassem -, reconfigurando então a problemática ética. Nietzsche, que interpretava a tragicidade da existência de modo atemporal e mais independente das configurações específicas, já havia antes apontado para a recolocação da problemática ética na modernidade em face da crise (moral) dos valores.

\section{A resposta ética}

As análises críticas "realistas" da cultura moderna e a disposição de não voltar "aos braços das velhas igrejas" impuseram a Nietzsche e Weber o desafio de um posicionamento coerente e digno. Por essa trilha adentramos pelo campo da ética. Um acordo preliminar dos autores está precisamente na defesa de um posicionamento ético à altura das "verdades" trazidas com a crise dos valores superiores. Nietzsche asseverava: “ 'Quanto de verdade suporta, quanto de verdade ousa um espírito?' - Isto se tornou para mim a verdadeira medida do valor" (VP, §476, p.323); em tom similar, Weber dizia dedicar-se às reflexões intelectuais para saber quanto de "verdade" suportava. A coragem de abrir a consciência para as evidências da época, sem contudo negar o mundo, aparecia como a virtude decisiva ao homem digno da sua sabedoria. Isso aponta, desde já, para a dimensão aristocrática das posturas éticas postuladas pelos dois autores.

Uma vez reconhecida a depreciação dos valores superiores, seja na versão do niilismo seja na versão do desencantamento, Nietzsche e Weber processaram a subjetivação ética do problema moral, desafiando os indivíduos - mas, acima de tudo, a si mesmos - a se posicionarem com dignidade no jogo das "forças" ou dos "destinos" que governam a existência ou o mundo. Pode-se dizer, então, que os atributos mais elevados do homem ético correspondiam a uma tentativa de resposta a um vazio de dignidade ou integridade presente nas posturas típicas dos homens modernos, das quais os dois pensadores procuraram se afastar. E o procuravam porque, afinal, não faziam apenas a idealização de uma ética, mas queriam com ela ser coerentes. Ambos buscavam contrapor-se a um tipo específico de personalidade moderna que Nietzsche denominou de o "último homem", a cuja crítica Weber explicitamente aderiu (ESO, $P V$, p.169). O "último homem" é aquele que vive na aridez de um mundo des- 
divinizado mas não tem forças para tirar disso as conseqüências devidas, tamanha a anarquia a que podem levar.

Weber não sistematizou tal qual Nietzsche a crítica aos "últimos homens". Quando lhes fez referência apresentou-os como aqueles que "inventaram a felicidade" como finalidade da ciência. Significa que Weber apropriou-se da "devastadora crítica feita por Nietzsche" com um propósito restrito: romper com a derradeira tentativa de conferir à ciência uma significação absoluta, sendo ela enquanto esfera cultural - ou seja, com referência a valores - também uma perspectiva. Mas quando adentramos os meandros das contraposições éticas realizadas por Weber para edificar a sua noção de personalidade responsável (ou íntegra) vemos claramente que os tipos humanos aos quais o pensador procura se opor muito mais guardam do "último homem" nietzscheano. No geral, trata-se do "convicto secular", por assim dizer, que desloca a confiança nos valores superiores do plano da transcendência para o plano da história e seu progredir.

Tomemos como referência as duas principais discussões do ideário ético em Weber, relativas ao cientista e ao político. Ele contrapôs igualmente a integridade das duas vocações basicamente ao "diletantismo acadêmico" e à "demagogia plebiscitária", por um lado, e ao apego às significações absolutas ou às convicções, por outro. De modo comum, a superficialidade e o idealismo são tomados como os grandes inimigos da integridade ética nas vocações política e científica. Superficialidade como sinônimo de falta de profundidade; idealismo como sinônimo de falta de distanciamento. Os tipos representativos destas duas posturas são, respectivamente: o tipo "comum", seduzido pelos apelos da ou perdido na rotina das vivências cotidianas, o caçador das vivências imediatas, o "sensualista sem coração" e o "especialista sem espírito" (EP, p.189 [EPEC, p.131]), um tipo superficial, mesmo que não ingênuo; e o tipo "religioso", o caçador de sentidos absolutos que submete as suas ações a fins inquestionáveis, o que lhe confere certa profundidade nos atos às custas de uma enorme ingenuidade e anacronismo face às condições desencantadas das ações no mundo moderno. Nietzsche, por sua vez, foi um adversário talvez ainda mais tenaz do idealismo (EH, Por que sou tão inteligente, §2), estendendo sua crítica à moral do "utilitarismo" e do instrumentalismo, repudiando os homens que erigem o mais útil como superior ao mais sensível, a praticidade como superior ao estilo; o utilitarismo como "o verdadeiro vício do novo mundo", que já "contagiava” a velha Europa (FW, §329). 
Todavia, muito próximo do ideário ético do "espírito livre" de Nietzsche, profundidade e distanciamento são as posturas que compõem a "integridade" para Weber, com as quais o indivíduo verdadeira e corajosamente procura "prestar contas do significado último da sua conduta"; são elas que conferem "espírito" ao especialista (Souza, 1997). A diferença básica é que enquanto o cientista experimenta tais posturas no plano da "ação reflexiva", em que se busca evidenciar a inter-relação de fatos e para o que se exige a "neutralidade axiológica", o político o faz no plano da "ação valorativa", mas cuja "distância em relação às coisas e homens" e "para com o próprio eu" é condição para viabilizar com objetividade as suas causas (ESO, $P V$, p.139-140).

Considerando-se o que foi exposto, decorre que Nietzsche e Weber deram um enfoque intimista ou subjetivista ao desafio ético. Na verdade, nestes termos, o pathos da integridade ética distinguia-se de dois âmbitos de referência pelos quais o coletivismo moral apresentava-se expressivo na modernidade cultural: 1) a crença na humanidade como uma irmandade de sentimento ou comunidade de valores; donde as análises críticas dos dois autores de toda a tradição cristã ocidental e do misticismo oriental; e 2) a crença na humanidade como uma associação universal calcada no uso virtuoso e esclarecido da razão, numa convergência de Weber e Nietzsche contra Kant. Há tanto a recusa de um acosmismo sentimental quanto de um universalismo racional como saídas éticas ou morais.

As duas recusas referem-se a uma coisa só: a ruptura com qualquer variante do absoluto ético, afirmando, ao contrário, a natureza essencialmente subjetiva e conflituosa da problemática ética. O que há de comum nas éticas como moralidades coletivas? O fato de serem crenças, de se embasarem em convicções, o que torna os seus proponentes por demais presos ao valor da ação em si mesma, ao invés de enfatizarem o valor do destino, na forma da "obra" (Nietzsche) ou da "vocação" (Weber) próprias. Voltadas para a necessidade de conferirem um sentido absoluto ou universal à existência, a doutrina cristã e a metafísica kantiana podem ser sentenciadas como modalidades de "rejeição do mundo" (Weber) ou de "negação da vida" (Nietzsche).

O resultado da ruptura com o absoluto ético é a descaracterização da ética como devoção ou como imperativo, para ser caracterizada como caráter, com o que acentuam-se virtudes tais como "coragem", "virilidade", "coerência", "integridade", "dignidade" e "honestidade", em detrimento de virtudes como a "bondade" e a "obediência". Numa palavra, há a ênfase em virtudes "guerreiras" e "aristocráticas" em detrimento de virtudes "santas" e "públicas". Contra as idealizações religio- 
sas e filosóficas, lança-se um desafio ao homem para que assuma a existência efetiva, considerando-se o que pertence à ordem das "realidades objetivas" (Weber) ou das "forças vitais" (Nietzsche). A resposta ética como crítica à idealização dos valores e o seu conseqüente distanciamento da realidade. Subtrai-se a ética do plano da moralidade para afirmá-la no plano da experiência mais íntima e, a rigor, incomunicável.

Adotando o racionalismo como perspectivismo epistêmico e a responsabilidade como perspectivismo ético, Weber procurou, ao seu modo, colocar-se acima do "bem e do mal". Semelhante a Nietzsche, via nas convicções absolutas o grande empecilho às perspectivas de profundidade e de distanciamento adequadas aos espíritos mais corajosos numa época desencantada. Também via como decisivo o enfrentamento das "ilusões morais". No plano do conhecimento, sua amoralidade reflete-se nas exigências da "neutralidade axiológica" e da "prova empírica", e, no plano ético, ela reflete-se na exigência de um compromisso com as conseqüências dos atos.

Com as comparações feitas até aqui, pode-se deduzir que as posturas éticas dos pensadores encontram-se alicerçadas em dois atributos decisivos: o realismo ético, com a afirmação do "ser" - idéias de "personalidade íntegra", em Weber, e de "estilo" e "devir", em Nietzsche - sobre o "dever ser", e o subjetivismo ético, com a afirmação da "vontade" sobre a "universalidade". Dois atributos que se encontram consubstanciados nas seguintes máximas éticas: "Eis-me aqui, não posso fazer de outro modo", na versão weberiana (ESO, $P V$, p.151), e "Torna-te o que és", na versão nietzscheana. $\mathrm{O}$ realismo responde por uma dose de resignação (ou pessimismo) contida em ambas as máximas, apontando ora para as forças racionais modeladoras de um mundo como destino (Weber) ora para as forças naturais modeladoras da vida como destino (Nietzsche). $\mathrm{O}$ subjetivismo reflete a enorme dose de coragem na qual a dignidade se edifica na personalidade ou no espírito, como capacidade de agir com distanciamento e profundidade em relação às pessoas e às coisas.

As duas expressões contêm, de fato, muito do que há de comum nos ideários éticos dos dois pensadores. Para Nietzsche o "torna-te o que és" é também um "não posso", no sentido do querer que sabe-se objeto do jogo do devir, que sabe da sua incapacidade de ir além do necessário e do singular; e, para Weber, o "não posso" é o modo de afirmação de uma personalidade e de seu caráter dentro da prisão dos "cordões demoníacos", em especial, o cordão da vocação mundana. Parecem estar, por caminhos distintos, aspirando a um mesmo ideal: a emergência de um espírito que possa encarar de frente a sua época e, nela, dar conta de sua 
tarefa ou de sua obra. Assim, a despeito das enormes diferenças implicadas, as duas máximas dão noção inequívoca da ética como caráter ou postura íntima diante do mundo.

\section{Parte II \\ Dos desencontros}

\section{A imagem geral da cultura}

Sem negar as afinidades que até aqui foram apontadas, os pensamentos de Weber e de Nietzsche refutam-se mutuamente em dois pontos decisivos: o âmbito das forças cujas manifestações cada autor dedica às suas reflexões e a natureza da obra ou da causa que querem empreender e com a qual esperam se dignificar. São diferenças substanciais que direcionam os tratamentos dados à questão da linguagem e do método bem como à questão da ética, diferindo-os. Grosso modo, enquanto Nietzsche dedicou-se às forças vitais (ou impulsos naturais) e seus modos de subjetivação cultural, ao mesmo tempo que procurou dignificar-se como um extemporâneo em relação aos tempos modernos, Weber dedicou-se às forças culturais e seus tipos de racionalizações históricas, ao mesmo tempo que desafiou a si mesmo a uma integração viril e responsável diante dos novos "titãs desencantados". Num caso, a vida é o horizonte último do pensamento, cujos "segredos" se descortinam no plano sensível; no outro, o horizonte último é a história, que tem na racionalidade a melhor perspectiva de compreensão e inserção. Se Weber distinguiu cultura e vida enquanto Nietzsche relacionou as duas dimensões, avaliando os fenômenos culturais da ótica da afirmação ou negação da vida, ambos o fizeram com igual intenção de combate à metafísica.

Trata-se de uma diferença de fundo que permite diferenciar os pensamentos quanto aos aspectos sobre os quais, antes, estabeleceram-se afinidades. $\mathrm{O}$ fato de um autor referenciar-se nas subjetivações e nos impulsos vitais e, o outro, nas objetivações e na consciência, faz com que as metodologias propostas e as éticas almejadas apresentem características díspares, separando uma concepção de transracionalidade vital e de liberdade ética de uma concepção de racionalidade reflexiva e de responsabilidade ética. Traduzida para o plano do conhecimento, essa diferenciação indica que, enquanto Nietzsche praticou uma linguagem poética e 
legisladora, capaz de roçar o "fundo secreto das coisas", para, através dela, imprimir uma vitalidade artística, Weber praticou uma linguagem técnica e sistematizadora, voltada para a compreensão das conexões empíricas, para, através dela, imprimir uma responsabilidade intelectual; o princípio da "neutralidade axiológica" seria tão estranho ao primeiro, quanto a interseção entre conhecimento e vida foi rejeitada pelo segundo. E se Weber destacou a incapacidade de criar valores como uma virtude e um dever do cientista deveras "profissional", Nietzsche viu nisso precisamente $o$ atestado maior da fraqueza do conhecimento que segue regras formais ao invés de representar os impulsos de vida do seu criador. Provavelmente o filósofo do "Torna-te o que és" enquadraria um cientista weberiano dentro da tradição socrática do "Conhece a ti mesmo", que, ironicamente, "significa talvez: "Deixa de interessar-te por ti! torna-te objetivo" (JGB, §80). Adepto de um pensamento de tipo "afirmativo" (Deleuze, 1981, p.18-19), Nietzsche concebeu a interpretação como "meio" para uma avaliação (o valor dos valores) e o filósofo como um criador de valores; Weber também via na interpretação um "meio", só que com o fim de explicação (a motivação causal dos valores). Quanto à ética, veremos por que Nietzsche provavelmente conceberia a ênfase na responsabilidade como uma derivação do velho ascetismo negador da vida, enquanto Weber procurou distanciar-se do misticismo de um Zaratustra.

Sobre a imagem geral da cultura apresentada na primeira parte, os aspectos que foram destacados como afins sofrem, obviamente, variações decorrentes dessa oposição nuclear entre um leitmotiv transracional e um leitmotiv racional. Em Nietzsche, o perspectivismo é sobremaneira o movimento múltiplo das forças vitais, cuja dinâmica de efetivação foi por ele denominada "vontade de potência". No mundo das ações, o pressuposto é de que "Todos os nossos atos são incomparavelmente pessoais, únicos, imensamente pessoais, nisto não há a menor dúvida, mas desde que os transcrevemos na consciência, não mais parece que assim seja. Este é o verdadeiro fenomenalismo, o verdadeiro perspectivismo da maneira que o entendo" (FW, §354). O perspectivismo essencial de Nietzsche remete ao nível inconsciente, na contramão da trajetória do perspectivismo weberiano. Os valores são tomados como condições de efetivação de forças, ou seja, condições de conservação e crescimento. São mesmo as forças que avaliam e interpretam, por isso não faz sentido praticar uma interpretação racionalista quando a consciência é tida como manifestação fenomênica da "vontade de potência". Para um olhar solitá- 
rio, como o queria Nietzsche, as objetivações sociais são "máscaras que não querem ser assim chamadas" ( $\mathrm{FW}, \S 365)$.

Contrariamente a Nietzsche, Weber estrategicamente posicionou o duplo caráter perspectivista e agonístico da cultura no âmbito da racionalidade. Para tanto, ele subscreveu a problemática dos valores e seus antagonismos ao contexto das ações e seus sentidos regulares, vale dizer, passíveis de uma reflexão de natureza causal. É que o perspectivismo racionalista por ele adotado prescreve o uso de procedimentos racionais precisamente para escapar do caráter inconseqüente de todo subjetivismo. Como vimos, a raiz do perspectivismo é o subjetivismo inerente a toda racionalização, mas as singularidades devem ser interpretadas por seus modos de racionalização. Embora contenha sublimações, a consciência não é meramente fenomênica, pois ela edifica e define efetividades; e, historicamente, estruturam-se realidades que pertencem cada vez mais ao governo da consciência. Afinal, "También lo racional, en el sentido de la 'coherencia' lógica o teleológica de una toma de postura teórica-intelectual o ético-práctica, ejerce y lo há exercido siempre poder sobre los hombres, por mui limitado e inestable que este sea y haya sido siempre frente a otros poderes de la existencia histórica" (EX, p. 528). Weber definirá a ação racional referente a fins como tipo específico de ação consciente e que serve de garantia tanto à objetividade do conhecimento quanto à responsabilidade ética. Com este tipo de ação ele lastreia o seu perspectivismo racionalista, precisamente porque ela implica a atenção para com os meios ou condições que definem o sentido e os motivos efetivos dos cursos de ação, bem como permite escapar aos erros do subjetivismo que governa os fins e as intenções. Não por acaso, Weber preferiu as idéias de valor aos juízos de valor (conceitos como "meios" e não como "fins"), no nível metodológico, e preferiu o valor das conseqüências ao valor das intenções, no nível ético.

Ao enfocar a problemática dos valores pelo percurso dos sentidos racionalizados, Weber não estava, obviamente, reduzindo os valores (e muito menos a existência) ao racional mas, sim, afirmando que é apenas no plano da racionalidade que eles lhe interessavam, onde podiam ser devidamente processados. Com isso, a cultura é caracterizada pelos traços perspectivista e agonístico na medida que nela há a cultivação de valores bem como a objetivação destes em modos conseqüentes de ação, por mais que eles também expressem a existência de motivos irracionais. Vale dizer: se a irracionalidade responde pela incongruência última dos valores, a percepção das incongruências, todavia, deve se dar consoante as manifestações objetivas, factuais e "coerentes" daqueles. Esta pers- 
pectiva de compreensão racional dos valores evidencia que, para Weber, o caráter significativo dos valores radica nos seus processos de objetivação e que somente através deles é que se pode realmente aferir tensões e incongruências, devendo as irracionalidades serem tratadas como "desvios" (WG, p.3 [ESI, 5]). No plano efetivo, porém, tais "desvios" lógicos correspondem a resíduos concretos, pois afinal "o cálculo do racionalismo coerente não realizou com facilidade uma operação perfeita, na qual não houvesse restos" (ESO, p.324).

Aproximamo-nos novamente do ponto de discordância intransponível entre os dois pensadores na relação que mantêm com a cultura em termos gerais. Nada mais estranho e "ilusório" ao pensamento nietzscheano do que o propósito weberiano de circunscrever o tratamento dos sentidos aos âmbitos da consciência e da razão, lançando mão para tanto de recursos neutralizadores dos juízos particulares e das intenções primeiras. De fato, em seu apego ao referencial da ação racional como fundamento da reflexão (conhecimento) e, em boa medida, da própria ação (ética), distinguindo-se racionalidade teórica e prática, Weber mostra-se profundamente kantiano e antinietzscheano.

Nas críticas que dirigiu a Kant, Nietzsche mostrou ter no filósofo a imagem de um dos últimos grandes representantes da tradição filosófica de culto à razão inaugurada com Sócrates. Para Nietzsche, não se tratava de afirmar o homem e a liberdade moral contra a natureza, mas sim a vida contra a moral, não afirmar o inteligível contra o sensível, mas sim o caráter eminentemente sensível de toda experiência mais elevada, o que se estende para as próprias vivências intelectuais; daí o desprezo declarado pelas vivências ou conhecimentos que se propunham, em alguma medida, desinteressados. Até porque "Nossos pensamentos [no âmbito da consciência] são a sombra de nossos sentimentos - sempre mais obscuros, mas vazios, mais simples do que estes" (FW, §179). Ao enfatizar o caráter fortemente interessado de toda criação humana, o filósofo não pensa o interesse como manifestação do "eu", mas como fluência espiritual de um princípio de potência.

Ao opor vida e moral, Nietzsche distingue "erro" e "ilusão": o primeiro pertence ao universo das aparências que compõem a vida, e a segunda pertence ao universo das idéias que compõem a moral. Apregoa, com isso, um conhecimento aberto à fluência da vida e ciente do seu caráter aparente, mas que se dê como vivência e, não, como reflexão fria. Para ele, enquanto apegados a uma racionalidade supra-sensível e potencializadora de um domínio efetivo das coisas da vida, filósofos e cientistas continuavam agindo conforme prescreve toda moral, ou seja, com a 
ilusão tipicamente humana de tentar conformar o mundo aos seus caprichos conscientes.

Nietzsche também foi um severo crítico da linguagem, de modo especial da linguagem presa ao formalismo. Queria, sim, ser um artista da linguagem. Para tanto, recusa-se a sistematizá-la por conceitos, aceita as suas "impurezas" e contradições, reconhece que todo exercício do pensamento é linguagem e que toda "certeza" nela cristalizada é, em última instância, apenas semântica. E quão distante Nietzsche se encontra do formalismo weberiano quando se trata das considerações sobre a linguagem, antes de tudo por não reconhecer a excelência da consciência para além da sua utilidade, pois, afinal, ele considerava que "toda ação perfeita é precisamente inconsciente e não desejada; a consciência expressa estado pessoal imperfeito e ordinariamente doentio" (VP, $\S 169$, p.167).

Nietzsche achava que o pensamento deve mergulhar e elevar-se além do factual e do objetivado, trilhando o caminho oposto da cristalização consciente, numa espécie de "dessublimação". Por isso sobrepôs a metáfora "intuitiva" à "conceitual", por isso aliou a ética ao conhecimento, por isso preferiu o aforismo aos longos textos e a poesia à teoria. Se Weber escolheu um estilo formal, objetivo e acadêmico para formular "verdades" factuais e evidentes, Nietzsche aderiu a um estilo informal, altamente pessoal e antiacadêmico para expor "verdades" pulsionais e polêmicas. Enquanto o cientista procurou superar a moralidade através do formalismo teórico e de uma orientação eminentemente reflexiva, apegando-se ao raciocínio das causas e conseqüências, o filósofo o fez através de uma linguagem com forte dose de poesia e crítica pessoal, com a qual buscava aproximar-se das sensações, mesmo corporais, e dos sentimentos mais íntimos.

\section{A interpretação crítica da cultura moderna}

Argumentei sobre a convergência interpretativa de Weber e Nietzsche quanto à depreciação moderna dos valores superiores, compreendendo-se a existência humana como desprovida de sentidos absolutos. Adiantei, contudo, que os autores fundamentariam de maneira diferente as razões da "perda" de significação cultural pela qual descortinava-se o "imoralidade" essencial da existência. Agora devo aprofundar este ponto. A diferença básica pode ser assim anunciada: 
enquanto Weber fundamentou a "perda de sentido" nos processos de cultivação racional dos valores que se revelavam - muitas vezes sob aporte formal - autônomos e incongruentes, Nietzsche fundamentou a questão na decadência inerente à dinâmica desses valores, que poderiam, uma vez desacreditados, ser transvalorados pelo "espírito livre". 7 Por vias díspares, o cientista destaca a afirmação racional dos valores e o filósofo destaca a decadência psicológica dos valores como condição fundamental da crise a que são levados, na disjunção de um olhar "objetivo", focado nas racionalizações culturais, para um olhar "subjetivo", focado nas subjetivações culturais. No diagnóstico da modernidade, há um choque interpretativo entre o apontamento do traço "ativo" do ascetismo que comanda o desencantamento e o traço "passivo" do niilismo ligado à morte de Deus. Dá-se a separação do cientista que vê o homem como agente enredado na intersubjetividade de configurações objetivadas e o filósofo que o vê como espírito definido pelas configurações de seu caráter; de qualquer modo, em ambos os enfoques, trata-se de configurações que escapam ao querer do agente, é bom não esquecermos.

Nietzsche situou o problema do antagonismo das forças, não tanto na relação entre elas, mas muito mais na dinâmica própria de cada complexo de forças. Compreende-se melhor essa idéia e o próprio traço subjetivo do tratamento dado à cultura pelo filósofo quando deparamos com sua interpretação do niilismo, ao qual radicalmente procurou se opor. Ele defendeu a tese de que o niilismo é conseqüência da própria natureza decadente das forças morais que se perpetuaram em valores superiores em especial a crença na "bondade" e na "verdade". Giacóia (1997) já recuperou a idéia do "destino" das forças decadentes como um processo de "auto-supressão da moral". O ocaso dos valores superiores não remete, portanto, à fragmentação objetiva dos mesmos em cursos de ação racionalizados, como dirá depois Weber, mas sim à fragmentação subjetiva, a um "anarquismo de forças" que, incapaz de uma hierarquização saudável, perdem sua capacidade de criação - daí o prestígio das posturas "igualitárias" e "conscienciosas". Como Weber, a crise dos valores é realçada como um vácuo de criação, para além de uma quebra de unidade, só que, ao invés de conformar-se ao caráter fragmentado do mundo e especificar para a política a tarefa de revitalização dos valores, como fará o sociólogo, Nietzsche concebeu a criação como potencial das almas

7 Weber, ao contrário, mesmo quando pensa em termos de "paradoxo das conseqüências", não se refere ao processo de ação internamente, mas ao fato de, no seu curso, as ações alentarem forças outras que se predispõem contra as intenções originais. 
mais elevadas, ou seja, como uma tarefa de ordem pessoal, infra-institucional e supra-histórica.

São diferenças cruciais que, novamente, remetem ao leitmotiv fundamental de cada pensamento. Em Weber há a convergência entre a idéia da racionalidade como princípio constitutivo das significações culturais e a visão das racionalizações modernas como os modos exemplares de efetivação histórica deste princípio, convergência na qual se lastra a estratégia do racionalismo metodológico quanto à racionalidade aplicada ao postulado da consciência ética. O racional na cultura, para Weber, é, antes de tudo, o que é elaborado conscientemente, ocupando um lugar no seu pensamento para além da questão da objetividade metodológico, servindo como substrato de um "perspectivismo último" que afeta diretamente as análises teóricas e a questão ética. E a interpretação das racionalizações modernas como correspondendo à efetivação de significações culturais com pretensões universais, embora não cristalizassem o inextricável destino humano, forçava e desafiava o indivíduo a se colocar à altura do "estágio" racionalizado da época e da sua própria consciência. Por isso, consoante o problema da inserção na cultura moderna, a proposição da ética como um problema de consciência, e, cada vez mais, de consciências cultivadas com os recursos da razão.

$\mathrm{Na}$ crítica de Weber à sobrevaloração operada por Nietzsche do ressentimento como a base psicológica de todo o moralismo ascético que caracteriza a tradição moderna, pensada como "revolta dos escravos", pode-se verificar a disparidade entre a valoração weberiana do "racional" e a valoração nietzscheana do "vital". Ele se insurgirá contra esta famosa interpretação psicológica não por considerá-la errada, mas por ser ela exagerada e simplista. ${ }^{8}$ Nietzsche teria sobrevalorizado os condicionamentos inconscientes no plano da história bem como reduzido a problemática dos valores à oposição entre dominadores e dominados. Procurará, então, estabelecer um enfoque mais racional e positivo das raízes do ascetismo que caracterizou a cultura moderna, afirmando que, muitas vezes, "O ressentimento não foi necessário como alavanca; o interesse racional nas compensações materiais e ideais, como tal, foi perfeitamente suficiente" (ESO, p.320). Do ponto de vista moral, a história do Ocidente não foi configurada tanto pelo ódio recalcado dos dominados,

8 Weber via, sim, um equívoco na interpretação quando ela se aplicava ao budismo (WG, p.286 [ES, 340]). Mas, neste caso, ele não fez uma leitura das últimas obras de Nietzsche, nas quais o filósofo procurou distinguir o budismo do cristianismo precisamente pela ausência do ressentimento no primeiro (AC, §20; EH, Por que sou tão sábio, §6). 
como pensava Nietzsche, mas muito mais por uma autovaloração simbólica empreendida especialmente pelas camadas urbanas voltadas para atividades práticas, muitas vezes com o espírito de "compensação" religiosa (e não tanto de revolta). Onde o filósofo vislumbrou reatividade, o sociólogo apontou uma positividade, sem querer julgá-la boa ou má.

$\mathrm{O}$ fato de o leitmotiv do pensamento weberiano - a sua abordagem racionalizada da cultura - afinar-se com as realizações da consciência, em especial o aperfeiçoamento do raciocínio causal e da institucionalização do que é regular, o coloca na contramão do perspectivismo subjetivista de Nietzsche. Este procurou, precisamente, um devido distanciamento do que se reputava serem os frutos mais elevados da consciência, por considerá-los as últimas grandes "ilusões", particularmente a ilusão de um mundo de "verdades" inteligíveis e das orientações principais da vida como prerrogativa especial da consciência. A consciência, para o filósofo, era considerada um órgão secundário, subordinado às sensibilidades. Consequentemente todos aqueles que aderem à consciência ou à razão como "faculdade" mais elevada - seja por "imperativo" (Kant), seja por "cultivação (Weber) - e que, para tanto, protegem-na dos sentimentos e dos impulsos mais primários, são considerados pensadores metafísicos atrelados ao ascetismo niilista negador das forças vitais.

Contrariamente a Weber, Nietzsche não via a modernidade cultural como um complexo de "esferas autonomizadas" conforme significações racionalizadas e passíveis de uma compreensão explicativa. O fundamental não eram os fenômenos de racionalização - sempre superficiais face aos fundamentos mais subjetivos da ação - mas, sim, o diagnóstico psicológico da "doença" da alma moderna, seu caráter decadente; para tanto ele se propôs a fazer uma genealogia das significações, ao invés de explicá-las. A genealogia não busca levar a interpretação até o apontamento das causas, para daí estabelecer previsibilidades objetivas, mas levá-la até o apontamento do valor das significações morais, para, com isso, permitir a vivência subjetiva da superação. O conhecimento, para Weber, tinha o propósito de exercer refutações e estabelecer probabilidades no campo das ações; já para Nietzsche, o conhecimento existia para impor-se e abrir possibilidades. De um lado, o intelectual que procurou manter-se aferrado aos ditames de uma consciência reflexiva, do outro, o poeta que procurou extrapolar os ditames da consciência até às portas da loucura - "Ah, que eu seja banido de toda a verdade! Só Doido! Só poeta!" (DD, p.25).

Weber enxergou no "racionalismo de domínio do mundo" um modo de vida inexorável, o qual se impunha aos homens, em boa medida, como 
uma "técnica de vida" (Souza, 1997, p.122), como um conjunto de orientações formais acopladas às regras da experiência. Nessa realidade, tornava-se um compromisso, mas também uma ousadia, ter que lidar com as exigências de um grande "demônio" - o "racionalismo de domínio do mundo". Nietzsche, por sua vez, enxergou as pretensões de hegemonia da razão, seja no âmbito intelectual ou no âmbito ético, como sintoma de um modo de vida decadente, uma configuração de forças desorientadas e enfraquecidas, e a maior ousadia consistia precisamente em não levá-las tão a sério, ser um iconoclasta do seu "império"; a aceitação e principalmente a adesão aos princípios de uma técnica de vida tão amoral era tida como a última expressão do moralismo ascético que percorria a história ocidental. As divergências, aqui, aproximam-se então do núcleo da questão ética.

\section{A resposta ética}

Na primeira parte procurei destacar as afinidades éticas através dos princípios do realismo (antiidealismo) e do individualismo (antiuniversalismo) presentes nas formulações sobre o homem digno, tanto em Weber quanto em Nietzsche, e como que tais traços conferiam às suas éticas um caráter de afirmação do "espírito", donde os atributos aristocráticos da coragem, da virilidade e da dignidade. Mas deparamo-nos com um problema que poderia ser formulado nos seguintes termos: Weber desejava o espírito à altura do seu tempo e de suas significações fragmentadas, enquanto Nietzsche desejava o espírito à altura da vida e precisamente contra tais significações. Certamente isso se dá porque, como interpretaram diferentemente as significações, localizaram as ações do espírito digno em "disposições" distintas: num caso, o ethos da consciência reflexiva, no outro, o pathos da sensibilidade artística. ${ }^{9}$ Weber e Nietzsche abordaram problemáticas afins munidos de alguns pressupostos comuns, mas o fizeram em registros diferentes. Estes registros poderiam ser eventualmente complementares caso não se estabelecessem fortes tensões entre eles, notadamente a tensão entre uma postura ética

\footnotetext{
9 Dadas as características díspares dos dois universos éticos, o que designamos como elementos da ética nietzscheana definem, na verdade, um pathos, e o que designamos como elementos da ética weberiana definem precisamente um ethos. Apoio-me, aqui, na própria deixa que o filósofo nos deu dessa diferenciação, quando esclareceu que a sua preferência pelos "hábitos breves" e pelas vivências pulsionais, mais intensas e transitórias, definem um pathos ao invés de um ethos ( $\mathrm{FW}, \S 317$ ).
} 
centrada no ideal de "inserção" crítica nas condições objetivas (responsabilidade) e uma postura ética centrada no ideal da "transvaloração" dos valores (extemporaneidade), da qual passo a tratar.

$\mathrm{Na}$ modernidade, Weber situou a problemática ética em relação às ações racionais, embora ela seja, em si mesma, irracional enquanto definida como uma vivência íntima. Entendeu ele que, para uma época marcada pelo "racionalismo de domínio do mundo", a ética apresentava-se associada a um dilema interno da racionalidade. Como o perspectivismo racionalista adotado por Weber pode ser caracterizado, em termos operacionais, pelo princípio da relação entre meios e fins, em torno desta distinção e da primazia que se dá aos "fins" ou aos "meios" é que se sustentam a duplicidade da tarefa metodológica (interpretação e explicação), a duplicidade das ações racionais (referência a valores ou a fins), a duplicidade da tipologia do ascetismo (intramundano e contemplativo) bem como a própria duplicidade da ética racional (convicção e responsabilidade). Para os intentos deste texto, é necessário, portanto, precisar melhor a relação entre ética e racionalidade em Weber.

Weber definiu que, para a sociologia, "um padrão 'ético' caracteriza-se por adotar como norma, para a ação humana que pretende para si o predicado de 'moralmente boa', determinada espécie de crença racional referente a valores" (WG, p.18-19 [ESI, 22]). Relativamente às "ordens sociais", as éticas têm um sentido de "garantia" interna. Outras vezes, porém, o ideal ético encontra guarita externa, realizando-se como convenção ou, mais excepcionalmente, como direito.

Na definição de "padrão ético", duas propriedades se destacam: o princípio da "interioridade" e o princípio da "moralidade". A dimensão moral das éticas se exacerba quando elas se fundamentam em crenças religiosas; e a interioridade, que define a ética como um problema de consciência por excelência, acentua-se precisamente quando falta a um padrão ético qualquer garantia externa. Uma questão importante então se coloca: como posicionar os dois padrões éticos aos quais Weber associou as ações racionais - convicção e responsabilidade - face à definição sociológica de "padrão ético"? Uma observação preliminar é que, como padrão sociológico de conduta, a ética adquire uma conotação mais normativa, enquanto que, como padrão racional de conduta, ela adquire uma conotação mais teleológica, envolvendo fins que se impõem ou como "absolutos" ou como "relativos", subordinados, neste caso, ao cálculo dos meios. ${ }^{10}$

Se tentarmos relacionar as éticas racionalizadas com os princípios da "interioridade" e da "moralidade" aplicados a um "padrão ético", com 
o primeiro não parece haver dificuldades, não só porque convicção e responsabilidade dizem respeito à condução da ação mas também porque Weber insistiu nisso - são decisões de foro íntimo. Com o segundo, porém, a adequação que se vê com a ação orientada por um fim absoluto, em que as condutas "fiéis" se tornam automaticamente "corretas", não se dá com a ação orientada pelas conseqüências, a qual necessariamente precisa suspender o predicado moral que acompanha a definição do "padrão ético". Segundo Weber, quem age responsavelmente o faz desprestigiando a ação como um valor próprio. Assim, a responsabilidade como padrão ético superior em tempos de extrema racionalização da vida prática e mental representa o confronto direto com a moralização e a normatização da ética. É que a crise dos valores superiores recolocava de modo radicalmente novo o problema ético, pois não se tratava mais do que é bom relativamente à ação, mas do que é autêntico e digno relativamente à personalidade. Torna-se imperativo, portanto, definir bem a noção de responsabilidade, núcleo da integridade ética weberiana.

O drama ético das ações racionais aplica-se especialmente à esfera da política, distanciando-se das esferas econômica (demasiadamente presa à máxima do êxito), religiosa (demasiadamente presa às convicções) e científica (demasiadamente distante da ação). Na política, especialmente se institucionalizada de modo racional, é que se coloca de forma premente a dificuldade de se compatibilizar os interesses ideais com as condições objetivas de possibilidade. Nas páginas finais do texto Política como vocação, ao reconhecer não ser possível prescrever a dosagem ideal de convicção e responsabilidade nas ações políticas, Weber sentenciou o que seria então mais decisivo para o homem verdadeiramente vocacionado para a política: uma integridade de caráter, a capacidade de assumir as conseqüências dos seus atos e das suas propostas, a ponto de dizer: "Eis-me aqui, não posso fazer de outro modo". Uma vez adquirida tal firmeza de caráter, é que o político equilibra-se melhor em seu drama ético, sendo capaz de aliar "razão" e "paixão".

Weber viu esse caráter como a derradeira integridade do indivíduo, o que talvez nos permita distinguir responsabilidade, enquanto atenção para com as conseqüências da ação, da integridade, enquanto compromisso com as significações últimas de uma escolha valorativa. Esta classificação, além de não se colocar como tal na obra weberiana, é apenas

$10 \mathrm{O}$ problema do sentido - que para uma compreensão racionalista é um atributo inerente à racionalidade - é mesmo uma questão teleológica. 
esquemática, uma vez que a atenção para com as conseqüências é o modo peculiar de uma consciência crítica responder pelos valores últimos que governam os seus atos. Ou seja, a responsabilidade é o sentido principal da integridade ética. Apenas as distinguimos para frisar que, num caso, estão em foco as conseqüências práticas e o êxito, enquanto que, num outro, estão em foco as conseqüências últimas e os pressupostos da ação. Neste último sentido, o problema ético do significado da conduta desloca-se da ação para a personalidade, do procedimento técnico-racional para a postura consciente, reforçando o princípio da interioridade inerente a toda e qualquer ética, ao mesmo tempo que se enfraquece o princípio moral do padrão ético fundado em convicções.

Outro argumento favorável à dupla conotação da questão ética em Weber é que ela projeta com mais precisão a ética para fora dos limites da política, apresentando a integridade como um desafio lançado aos espíritos mais elevados em suas diferentes tarefas. Dito isso, mesmo o religioso, irresponsável quanto ao problema das causalidades objetivas, pode revelar-se um homem íntegro, desde que assuma com coerência o significado último das suas escolhas - no caso, as conseqüências do sacrifício do intelecto. Em termos substantivos, a atitude eticamente mais digna estende-se mesmo às esferas tipicamente irracionais e distantes do modelo de ação compromissada. É o caso do erotismo, onde o amante íntegro é aquele que consegue dedicar-se à amada "até o pianíssimo da velhice" (SS, p.395 [EX, 552]). ${ }^{11}$ Por essa abrangência, ficam patentes as limitações que envolvem a total subtração do ideário ético weberiano ao âmbito da racionalidade e à noção de profissão. Com isso, vale frisar o seguinte: Weber não restringe a integridade ética às esferas tipicamente racionalizadas, se pela idéia entendemos o compromisso último que o indivíduo assume diante dos valores que guiam a sua ação enquanto uma personalidade consciente do seu "ser" e do seu "fazer". Tendo sempre em vista que a condição cultural para isso é uma efetiva delimitação dos campos valorativos, inclusive aqueles extracotidianos.

A ética continua sendo, essencialmente, uma questão de posicionamento para além dos cuidados introduzidos em relação aos procedimentos. E é verdade que, integrada à noção de integridade, a responsabili-

11 Weber expressa-se em termos do amante eticamente "responsável". Sendo assim, poderíamos ter representado o par responsabilidade/integridade na forma de uma dupla conotação do termo responsabilidade: uma pragmática e outra substantiva. Porém, não fizemos isso para evitar maiores confusões e melhor delimitarmos a tensão com a ótica das convicções. 
dade aproxima-se sensivelmente da noção de conviç̧ão. Weber explicitou essa aproximação quando tratou do âmbito da política. Mas há uma importante distinção na medida em que a convicção, tradicionalmente, é sinônimo de devoção irrefletida, enquanto a integridade a que o homem moderno é desafiado exige a consciência das conseqüências ou das renúncias que acompanham toda ação. No caso da atenção para com as conseqüências, é na política que melhor se vislumbra a noção de integridade como sinônimo de uso responsável da convicção, representando a política, desse modo, um paradigma ético. Mas, de um modo extensivo a outras áreas da vida, não se trata mais de fidelidade e de uma subjetividade cegada pelos valores, mas de uma honestidade e de uma subjetividade iluminada pela reflexão racional. Considerando-se o requisito reflexivo, o religioso ou qualquer outro tipo muito convicto de homem, embora possa ser íntegro, não se mostra responsável. A ética weberiana é uma efetiva valoração da responsabilidade para dosagem das convicções.

É certo que as efetivas discussões de Weber sobre a ética centraram-se nas esferas cotidianas e, portanto, em íntima relação com o campo da racionalidade. Além da política, a conotação substantiva da responsabilidade foi particularmente realçada na esfera intelectual, à qual, afinal, Weber dedicou-se. Pois se a conotação substantiva da ética define a idéia da "integralização" possível de uma personalidade sob condições de fragmentação e desencantamento, a ciência é o modo mais radical de enfrentamento das conseqüências dessas condições, uma vez que só ela faz reflexivamente o "sacrifício moral". Weber sentenciou: "Pero alli donde el conocimiento racional empírico realiza consecuentemente el desencantamiento del mundo, transformándolo en um mecanismo causal, aparece plena la tensión contra el postulado ético de que el mundo es un universo ordenado por Dios y que, por tanto, se rige por un sentido ético" (EX, p.552).

A adesão weberiana à ciência empírica corresponde ao enaltecimento dela como configuração histórica mais universalista e mais crítica que o pensamento humano delineou face aos fatos da existência. A ciência representa o procedimento mental mais elaborado de negação dos valores superiores, operando um desencantamento mais conseqüente e capaz de "forçar o indivíduo" - via raciocínio causal e evidências empíricas - "a prestar a si mesmo contas do significado último da sua própria conduta" (WB, p.267 [ESO, 179]). E é interessante observar como essa potencialidade ética mais ampla das ciências empíricas - a qual Weber resume no valor da clareza intelectual - está associada à possibilidade de 
nelas se realizar a ruptura mais definitiva com a moralização da ética. Afinal, no ocidente, "el intelecto creó una aristocracia de la posesión de la cultura racional, independiente de todas las cualidades ético-personales de los hombres y, por ello, no fraternal" (EX, p.558). Ao separar as questões do ser e do dever ser a ciência por certo não elimina a segunda, mas enfrenta de modo mais decisivo as premências da primeira num mundo racionalizado. Os "demônios" se objetivaram e o perspectivismo dos valores moldou realidades inexoráveis, extremamente previsíveis, um "destino", pode-se dizer - embora não uma eternidade, onde reinam forças ininteligíveis. ${ }^{12}$ Não mais convicções, mas condições; não mais ingenuidade, mas desencantamento. $\mathrm{O}$ ascetismo religioso moldou o mundo e favoreceu a fixação de condições que lhe imprimiram o caráter mundano de obrigação prática, não mais espiritual.

Do ponto de vista weberiano, o grande erro de Nietzsche - quiçá a ingenuidade - foi ter subestimado o poder de "estruturação", "regularidade" e "domínio" de um destino racionalizado, foi ter interpretado a consciência racional como "o que há de menos acabado e menos forte" no homem, foi não ter percebido que as racionalizações expressam uma sofisticação "adaptativa" com custos intransponíveis ao espírito (se para o "bem" ou para o "mal", não vinha ao caso da ciência), enfim, foi não ter reconhecido a autonomia das efetividades racionais. Como Nietzsche associou o espírito livre ao pensamento mítico por ver neste a aparência simbólica de uma sabedoria trágica, esta postura, para Weber, corresponde perfeitamente à migração dos valores superiores para o "reino transcendental da vida mística", onde, em pianíssimo, ainda "pulsa alguma coisa que corresponde ao pneuma profético" (WB, p.272 [ESO, 182]). Uma escolha digna ao se distinguir da busca por soluções universais, mas, sem dúvida, distante do essencial das sociedades ocidentais modernas: a sua estruturação racional e o seu caráter desencantado, com a inevitável fragmentação da cotidianeidade e das próprias almas.

Weber valorou de modo especial o espírito que encarava as últimas conseqüências dessa realidade, e o fez não meramente para se conformar mas, sobremaneira, para comprometer-se. A ética em Weber está longe de ser mera resignação, por mais que se encontre centrada na atenção para com as conseqüências da ação e adquira, assim, um inegável sentido

12 O destino como eternidade é o que de fato está à frente do nosso tempo, e não a ciência ou qualquer outra esfera racionalizada. Numa passagem, com o propósito de realçar o caráter essencialmente irracional da existência, Weber disse ainda que a medicina não pode dar sentido à vida, por mais que esteja voltada para a sua conservação (WB, p.257 [ESO, 170-171]). 
de integração. A consciência diante das condições das ações é um desafio lançado ao espírito de se integralizar em uma disposição de vida apesar da falta de liberdade e de sentido universal que passam a caracterizar as experiências mundanas, superando tanto as ingenuidades quanto o apego pouco crítico às vivências. Sendo um exercício corajoso da consciência desencantada, não parece indevido pensar a responsabilidade ética como a experiência maior de liberdade possível e autocompreensão do espírito. Uma potencialidade que se torna extremamente subjetiva e intimista no mundo moderno, como prerrogativa da alma que "escolhe o seu próprio destino - isto é, o sentido do seu fazer e do seu ser" (SW, p.197-198 [MCSII, 374]).

O papel decisivo que Weber conferiu à responsabilidade como padrão ético implica o necessário reconhecimento da renúncia que há por detrás de toda ação num mundo recortado por significações parciais e inconciliáveis. A renúncia é a contraface do compromisso com os "meios" decisivos com os quais o agente tem que lidar - no caso da política, a violência; no caso da ciência, as causalidades objetivas -, que, ao imporem suas conseqüência últimas, obviamente limitam as possibilidades; a renúncia é condição de um espírito que se tornou "desperto". A partir desta idéia, podemos melhor inserir os desencontros com Nietzsche. É que toda a ética nietzscheana visa precisamente a abundância e transbordamento potencial das ações mais livres - aquelas que se colocam "além do bem e do mal" - em lugar da ênfase na contenção. Nietzsche definia os fortes como aqueles que sofrem por abundância (FW, §370).

Porque, para o filósofo, o ideário ético não se traduzia no estar à altura da sua época, como desejava Weber, mas sim em estar à altura da vida. Em tempos de niilismo passivo - sintomatologia das forças decadentes - deve-se mesmo colocar-se noutro campo valorativo; por isso Nietzsche vangloriava-se de ser "extemporâneo" ou de ter nascido "póstumo", como gostava de dizer. A expressão que traduz o seu descompromisso com a tradição moderna é "transvaloração de todos os valores", e a expressão que traduz a afirmação incondicional da vida como devir, do princípio da abundância sobre o princípio da integração, é "amor fati".

Esta última expressão, pelo caráter que assume, torna-se o núcleo significativo do que poderíamos considerar uma ética nietzscheana. Designa a idéia maior do espírito disposto a receber a vida como acaso, o acaso como necessidade e a necessidade como eternidade: "Minha fórmula para grandeza do homem é amor fati: nada querer diferente, seja para trás, seja para frente, seja em toda eternidade. Não apenas suportar o 
necessário, menos ainda aceitá-lo - todo idealismo é mendacidade contra o necessário - mas amá-lo..." (EH, Por que sou tão inteligente, §10). Embora a ética weberiana também se centre numa aceitação do necessário, a idéia nietzscheana de necessidade apresenta distinções: não se trata de "exigências do momento", de um destino histórico, mas de exigências de todo momento, da eternidade; não se trata de exigências das quais podemos ter consciência e com as quais devemos ter responsabilidade, mas de exigências que remontam ao caráter arbitrário de todo acontecimento, cuja percepção é da ordem da sensibilidade e do prazer.

A ética como estilização (amor) do caráter (fati). Ou: "torna-te o que és". Mas o que és? O que é o "ser" para Nietzsche? Acontecimento, acaso, devir. Nietzsche propõe: não mais Deus como a vida ("niilismo negativo"), não mais a vida divinizada ("niilismo reativo"), menos ainda a vida anatematizada ("niilismo passivo"), mas a vida amada em sua arbitrariedade e a despeito da nossa mortalidade e dos riscos da exposição ao acaso ("niilismo ativo"). ${ }^{13} \mathrm{~A}$ vida como a "serpente" que nos dá a perspectiva e o abismo.

Não detalharei aqui a idéia central do "eterno retorno", pela qual Nietzsche sintetizou a sua compreensão da relação do homem com a eternidade e da ética com uma cosmologia. Sobre ela, direi apenas algumas palavras. $\mathrm{O}$ espírito nietzscheano expressou através de pensamentos as suas mais excelsas criações. Os pensamentos como reflexos da espiritualização como obra de arte. E, nesse domínio do artístico, uma idéia projetou-se como signo da obra nietzscheana, que o filósofo denominou o seu "pensamento abismal": a idéia do eterno retorno. A essência do pensar nietzscheano consiste no diálogo da alma consigo mesma enquanto perpassada pelo cósmico e pelo eterno; pelo menos foi assim que o filósofo quis o seu pensamento vivido, contra o pensamento analítico que é o diálogo da alma com o exterior, o estranho, o impessoal. O "pensamento abismal" sintetiza o posicionamento cosmológico do espírito. O espírito compreende-se não apenas como uma configuração psíquica e cultural de base corpórea; ele sente-se parte de um "todo" que não pode ser avaliado; existir é incomensuravelmente um ato de irresponsabilidade: "A fatalidade de seu ser não pode separar-se da fatalidade de tudo o que foi e será" (CI, Os quatro grandes erros, §8). Nietzsche aspirou tomar a vida, com sua pletora de acontecimentos casuais, como uma providência pessoal; a fatalidade como predestinação (FW, §277). Ele

13 Faço aqui uma aplicação das classificações do niilismo adotadas por Roberto Machado (1997). 
exprimiu isso também pela noção de "sentido da terra" ou predestinação terrena para a vida. Sentir-se cósmico, experimentar as forças mais inauditas, querer-se distante das significações históricas, ousar os atos de loucura: assim Nietzsche concebeu a superação em si.

O eterno retorno é uma idéia intuitiva, sentimental, antes de ser uma doutrina relativamente sistemática, tal qual veio a ser apresentada por Nietzsche: como lógica do jogo infinito das forças finitas. Neste sentido, a experiência momentânea do eterno retorno é mais do que um mero pensar; é um sentimento de forças que se expressa como abertura para a experimentação intensa e profunda do vivido. O eterno retorno não é uma ciência, no sentido que não pode ser avaliado tecnicamente, nem é uma mística, no sentido que não se trata da sua experiência como possessão. Trata-se de uma filosofia de vida, um pensamento-afeto ou um pensamento-valor.

Voltamos assim ao tema central do pensamento nietzscheano: a vida. Frente a ela, o extremo da integridade ética está no "sim" incondicional, do qual só é capaz quem sabe "rir" de toda seriedade ascética. A alegria é a chancela do eterno, porque "a dor diz 'passa momento!'/ Mas todo prazer quer eternidade" (ZA, A canção do sonâmbulo). Lembremos da afinidade estabelecida entre a máxima weberiana "Eis-me aqui, não posso fazer de outro modo" e o "eu quero" nietzscheano. Há também um paralelo da diferença. O "não posso" do cientista denota a extrema cotidianeidade que demarca a sua concepção ética, no que Nietzsche talvez visse um excesso de conformismo. Contrariamente, o "eu quero" do artista-filósofo denota a extrema extracotidianeidade que define a sua concepção ética, tendendo, ao juízo de Weber, para o misticismo e o psicologismo (WG, p.285-286 [ESI, 339-40]).

Argumentei sobre a semelhança dos autores quanto à radical subjetivação da ética no contexto da crise dos valores superiores, quando aquela se dissocia da moralidade tradicional ao não mais valorizar as ações ou as intenções em si mesmas. A ênfase deslocava-se para o espírito e a capacidade deste imprimir sua marca no que faz. Ganhava relevo a dimensão da paixão, igualmente pensada pelos autores como dedicação "objetiva" a uma "causa". Em Nietzsche podemos verificar essa idéia no seu livro mais autobiográfico, Ecce Homo, e, em Weber, na concepção do herói político como um homem sóbrio (ESO, $P V$, p.151-3). A partir desse entendimento comum abre-se, contudo, um grande fosso entre o cientista e o filósofo, pois enquanto Weber entende a afirmação da subjetividade como um exercício calcado na consciência, adensando à paixão a idéia de "dever" e, à causa, um sentido de profissão, ao mesmo tempo em que 
relaciona esta última com exigências objetivas, Nietzsche entende a afirmação da subjetividade como o governo dos impulsos mais íntimos.

A ética nietzscheana é uma flexibilização da consciência até o abismo do último humanismo. O que mais desagrada a Nietzsche na ética kantiana? A idéia do homem como fim e a subordinação deste "fim" aos fins da razão; ou seja, repudia uma fundamentação transcendentalista da ética. Como não gosta da idéia do supra-sensível, Nietzsche funda a ética no plano sensível, no plano da efetividade das forças naturais. Neste, $o$ homem - como tudo o mais que tem vida - é apenas um "meio", uma condição de efetivação de força, um valor, uma interpretação. Nietzsche prioriza o movimento sobre a forma: em sendo, o homem é devir. A ética da transvaloração de todos os valores não aponta para a humanidade, mas para o "além do homem". Daí o Übermensch como síntese do tipo ético nietzscheano. Por isso, em contraponto à historicidade weberiana, pode-se dizer que Nietzsche funda a sua ética numa espécie de cosmologia existencial.

\section{Palavras finais}

Quanto às afinidades entre os pensamentos de Nietzsche e de Weber, a tese fundamental apresentada foi de que uma imagem da cultura como universo de valorações conflituosas somada a uma interpretação da modernidade centrada na idéia da depreciação dos valores superiores alentaram uma forte subjetivação e amoralização da problemática ética. O indivíduo é "convidado" a dar, ele próprio, sentido à sua presença no mundo, sabendo de antemão que as forças da vida ou da cultura lhe escapam ao controle e remontam a um fundo inexplicável. A modernidade ocidental compõe uma trajetória que permite aos homens mais corajosos e dignos compreenderem que o destino continua trágico como descrito pelo politeísmo grego.

Quanto aos desafetos, não são de menor monta. Como ocorre entre a linguagem e os acontecimentos, há também um hiatus irrationalis entre a adesão do cientista a um ethos racional e a adesão do filósofo a um pathos artístico. Por isso, Weber e Nietzsche apresentam pontos inconciliáveis em aspectos metodológicos, expressivos e éticos. Para este último, salta aos olhos a disparidade entre o ideário de uma subjetividade cultivada com os "recursos" da consciência, a fim de se colocar à altura das objetivações culturais para "suportar" o domínio dos "deuses" munda- 
nos, e o ideário de uma subjetividade cultivada com os "recursos" da fisiologia e dos sentimentos mais pessoais, a fim de se colocar à altura das forças vitais que dirigem a vida para "transcender" a modernidade cultural. Um quer a responsabilidade de ir às últimas "conseqüências", o outro quer a extemporaneidade de ir às últimas "aparências". Como pano de fundo, Nietzsche aferrou-se ao princípio da vida como continuidade, daí o seu desconforto com o apego às falsas descontinuidades geradas pela consciência, enquanto Weber viu a descontinuidade deslocar-se do plano da abstração para ganhar conformações impessoais inescapáveis, como cursos de ações com legalidades próprias.

Entre a familiaridade e o estranhamento, dois autores que pertenceram a um mesmo contexto de época e que compartilham uma mesma obsessão: construir respostas intelectuais e éticas - relativas ao conhecimento e às vivências - aos abalos que processos mais contemporâneos provocaram em toda a tradição cultural do Ocidente. A moral estava destronada e os espíritos práticos perderam sua grandeza aristocrática. Havia então o desafio de um posicionamento mais digno. A idéia do posicionamento é a exigência de um comprometimento incondicional e subjetivo do homem com o destino; é a isso que corresponde basicamente a noção de "resposta ética" neste texto. Weber associou o destino à história e suas configurações regulares e impessoais, enquanto Nietzsche o associou ao devir e suas configurações mais intempestivas e pessoais. Com isto, fizeram escolhas que, em suas perspectivas últimas, mais se assemelham a duas linhas paralelas.

Belo Horizonte, abril de 2003

NOBRE, R. F. Weber, Nietzsche and the ethical answers to the critique of modernity. Trans/Form/Ação, (São Paulo), v. 26, p.53-86, 2003.

- ABSTRACT: The article consistes in a comparative study between Friedrich Nietzsche's and Max Weber's conceptions of culture, their critical analyses of modernity and the ethical answers that follow from them. In spite of the impor- 
tant affinities between the two authors, the article tries to show that the main character of the comparison is that of the divergence and incompatibility.

- KEYWORDS: Culture; modernity; ethics; rationality.

\section{Referências bibliográficas}

Nietzsche:

DD - Ditirambos de Diónisos. Lisboa: Guimarães Editores, 1993.

ZA - Also Sprach Zarathustra. Stuttgart: Reclam, 1994 (Assim falou Zaratustra. Rio de Janeiro: Bertrand do Brasil, 1995).

EH - Ecce homo - como alguém se torna o que é. São Paulo: Companhia das Letras, 1995).

FW - Fröhliche Wissenschaft. Stuttgart: Reclam, 1996 (A gaia ciência. São Paulo: Companhia das Letras, 2001).

JGB - Jenseits von Gut und Böse. Stuttgart: Reclam, 1999 (Além do bem e do mal. São Paulo: Companhia das Letras, 1992).

$\mathrm{AC}-\mathrm{O}$ anticristo - maldição do cristianismo. Rio de Janeiro: Newton Compton Brasil Ltda., 1996).

VP - Vontade de Potência. Rio de Janeiro: Ediouro, s/d.

CI - Crepúsculo dos Deuses. São Paulo: Hemus, 1984.

GM - Genealogie der Moral. Stuttgart: Reclam, 2000 (Genealogia da moral. São Paulo: Companhia das Letras, 1998).

Weber:

WG - Wirtschaft und Gesellschaft, I. Tübingen: Verlag von J.C.B Mohr, 1947.

ES - Economia e sociedade, vol. I. Brasília/DF: Ed. UNB, 1991).

SW - Schriften zur Wissenschaftslehre. Stuttgart: Reclam, 1991.

SS - Schriften zur Soziologie. Stuttgart: Reclam, 1995.

WB - Wissenschaft als Beruf (in SW).

ESO - Max Weber - ensaios de sociologia. In: MILLS, W., GERTH, H. (org.). Rio de Janeiro: Zahar Editores, 1982.

$\mathrm{PV}$ - A política como vocação (in ESO).

EX - "Excurso - Teoría de los Estadios y Direcciones del Rechazo Religioso del Mundo". In: Ensayos Sobre Sociología de la Religión, I. Madri: Taurus, 1992.

MCSII - Metodologia das ciências sociais (parte II). São Paulo: Cortez, 1995. 
PE - Die Protestantische Ethik I - Eine Aufsatzsammlung. Munique/Hamburgo: Siebenstern Taschenbuch Verlag, 1969.

EPEC - A ética protestante e o espírito do capitalismo. São Paulo: Pioneira, 1997.

\section{Outros autores}

DELEUZE, G. Nietzsche. Lisboa: Edições 70, 1981.

GIACÓIA JÚNIOR, O. Labirintos da alma - Nietzsche e a auto-supressão da moral. Campinas: Editora Unicamp, 1997.

MACHADO, R. Zaratustra - tragédia nietzschiana. Rio de Janeiro: Jorge Zahar Editor, 1997.

SOUZA, Jessé. Patologias da modernidade: um diálogo entre Habermas $e$ Weber. São Paulo: Anablume, 1997. 